\title{
Determination of phosphorus and metals in human brain proteins after isolation by gel electrophoresis by laser ablation inductively coupled plasma source mass spectrometry
}

\author{
J. Sabine Becker, ${ }^{* a}$ Myroslav Zoriy, ${ }^{a}{ }^{\text {J. Susanne Becker }},{ }^{b}$ Carola Pickhardt ${ }^{a}$ and \\ Michael Przybylski ${ }^{b}$ \\ ${ }^{a}$ Central Division of Analytical Chemistry, Research Center Juelich, D-52425 Juelich, \\ Germany.E-mail: s.becker@fz-juelich.de \\ ${ }^{b}$ Laboratory of Analytical Chemistry, Department of Chemistry, University of Konstanz, \\ D-78457 Konstanz, Germany
}

Received 15th September 2003, Accepted 24th October 2003

First published as an Advance Article on the web 8th December 2003

\begin{abstract}
Phosphorus, sulfur, silicon and metal concentrations ( $\mathrm{Al}, \mathrm{Cu}$ and $\mathrm{Zn}$ ) were determined in human brain proteins by laser ablation inductively coupled plasma mass spectrometry (LA-ICP-MS) after separation of protein mixtures by two dimensional (2-D) gel electrophoresis. The analysis of phosphorus, silicon and metals in single protein spots in the gel was performed with an optimized microanalytical method using a double-focusing sector field inductively coupled plasma mass spectrometer coupled to a commercial laser ablation system (LAICP-MS). Relative ion intensities for $\mathrm{P}, \mathrm{Si}$ and metals with respect to sulfur in protein spots were determined by LA-ICP-MS. The detection limits for phosphorus and sulfur in protein spots with a silver staining procedure on the 2-D gels were compared with the Coomassie staining technique described previously.
\end{abstract}

\section{Introduction}

Laser ablation ICP-MS (LA-ICP-MS) is a powerful mass spectrometric technique for fast trace element determination and isotope analysis and it has been used to an increasing extent for microlocal analysis of solid materials. ${ }^{1,2}$ The development of microanalytical techniques involving LAICP-MS for element determination in biological and medical samples is a challenging task. Special interest has recently focused on the determination of phosphorus in proteins. ${ }^{3-5,16}$ In these experiments LA-ICP-MS was applied for microlocal analysis of phosphorus in selected protein spots in two dimensional gels after 2-D gel electrophoresis. A major problem is the quantification of analytical data, therefore new quantification strategies for direct microlocal analysis of phosphorus in protein spots are required. Marshall et al. ${ }^{5}$ have developed a simple quantification strategy for phosphorus determination in protein gel spots which showed good detection sensitivity for $\beta$-casein. We have recently described a solution based calibration strategy for quantitative phosphorus determination in proteins in 2-D gel by LA-ICP-MS. ${ }^{3}$

A serious disadvantage and limiting factor of LA-ICP-MS (and also of ICP-MS) for the determination of monoisotopic phosphorus at $\mathrm{m} / \mathrm{z} 31$ are isobaric interferences of high intensity such as ${ }^{15} \mathrm{~N}^{16} \mathrm{O}^{+},{ }^{14} \mathrm{~N}^{17} \mathrm{O}^{+}$and ${ }^{14} \mathrm{~N}^{16} \mathrm{O}^{1} \mathrm{H}^{+}$. For the separation of isobaric interferences, a double-focusing sector field ICP-MS (ICP-SFMS) with sufficient mass resolution $(m / \Delta m \geqslant 1500)$ has been applied to phosphorus determination in protein samples. An alternative approach is the application of ICP-MS with a dynamic reaction cell by measurement of ${ }^{31} \mathrm{P}^{16} \mathrm{O}^{+}$molecular ions, proposed by Baranov et al. ${ }^{6}$ This technique is useful if no sector field ICP-MS is available. However, at optimized experimental conditions we found significantly lower detection limits by ICP-SFMS $\left(20 \mathrm{pg} \mathrm{g}^{-1}\right)$ for phosphorus determination in aqueous solution in comparison to quadrupole based ICP-MS with a collision cell (ICP-CC-QMS) $\left(1.3 \mathrm{ng} \mathrm{g}^{-1}\right)$. $^{7}$

In our previous work ${ }^{7}$ the Coomassie staining technique for visualization of protein spot in 2-D gel was applied, which provided a relatively high background of $\mathrm{P}$ and $\mathrm{S}$ in gel and protein spots and therefore high detection limits for both elements. To improve the detection limits for selected elements of interest, silver staining of separated protein spots in 2-D gels has been studied. Via the determination of phosphorus concentration by LA-ICP-MS, the occurrence of phosphorylations in proteins can be identified, a most important posttranslational modification which is of crucial relevance for many physiological as well as pathophysiological processes such as in carcinogenesis and neurodegenerative diseases. ${ }^{8,9}$ Numerous recent studies have established soft ionisation biological mass spectrometry using electrospray (ESI) and matrix assisted laser desorption ionisation (MALDI) as powerful techniques for the identification and structure determination of proteins from biological material, including the determination of post-translational modifications such as glycosylation, fatty acylation and phosphorylation. ${ }^{10-12}$ While MALDI and ESI mass spectrometry are efficiently used for the identification of phosphorylation structures in proteins, 3,13 these techniques cannot provide direct quantitative determinations of phosphorus and metals in biological samples.

In the present study, we have developed a direct microlocal technique for protein gel spots using LA-ICP-MS for the simultaneous multielement determination of phosphorus, sulfur and other elements (silicon, copper, zinc and aluminium) which were detected in human brain sample with Alzheimer's disease.

\section{Experimental}

\subsection{LA-ICP-MS instrumentation}

A double-focusing sector field ICP-MS (ICP-SFMS, ELEMENT, Finnigan MAT, Bremen, Germany) coupled with a commercial laser ablation system LSX 200 (Cetac LSX 200, Cetac Technologies, Omaha, NE, USA) was used for the microlocal analysis of phosphorus and sulfur, silicon and selected metals in protein spots. The ablated material was transported by argon as a carrier gas into the inductively coupled plasma (ICP). The ions formed in the ICP were extracted in the sector field mass spectrometer and separated according to their mass-to-charge ratios. To separate interfering molecular ions from atomic ions 
${ }^{31} \mathrm{P}^{+},{ }^{32} \mathrm{~S}^{+},{ }^{28} \mathrm{Si}^{+},{ }^{27} \mathrm{Al}^{+},{ }^{63} \mathrm{Cu}^{+}$and ${ }^{64} \mathrm{Zn}^{+}$, all LA-ICP-SFMS measurements were performed at a mass resolution of $m / \Delta m 4000$. The ${ }^{31} \mathrm{P}^{+}$ions are clearly separated from ${ }^{15} \mathrm{~N}^{16} \mathrm{O}^{+},{ }^{14} \mathrm{~N}^{17} \mathrm{O}^{+}$and ${ }^{14} \mathrm{~N}^{16} \mathrm{O}^{1} \mathrm{H}^{+}$, hence providing accurate phosphorus determinations. For the sulfur determination the most abundant interference of ${ }^{16} \mathrm{O}_{2}{ }^{+}$ions at $m / z=32$ is separated using ICP-SFMS at medium mass resolution. The ICP torch was shielded with a grounded platinum electrode (GuardElectrode ${ }^{\circledR}$, Finnigan MAT). For calibration a single gas flow solution-based procedure was applied using an ultrasonic nebulizer (USN, Cetac Technologies) described elsewhere. ${ }^{3}$ Using this arrangement, simultaneous optimization of the nebulizer gas flow rate for the USN and the carrier gas flow rate for the transport of laser-ablated material in ICP is possible. The experimental parameters of LA-ICP-MS were optimized with respect to the maximal ion intensity of ${ }^{31} \mathrm{P}^{+}$ using a $1 \mu \mathrm{g} \mathrm{L}^{-1}$ phosphorus solution introduced by the USN, which is coupled on-line to the laser ablation chamber. Maximal ion intensity was observed at a carrier gas flow rate of $1 \mathrm{~L} \mathrm{~min}^{-1}$ for the transport of ablated material to the ICP-MS and an optimal mixing of nebulized standard solutions and laser-ablated solid sample directly in the ablation chamber is possible. The background intensity of ${ }^{31} \mathrm{P}^{+},{ }^{32} \mathrm{~S}^{+},{ }^{28} \mathrm{Si}^{+},{ }^{27} \mathrm{Al}^{+},{ }^{63} \mathrm{Cu}^{+}$and ${ }^{64} \mathrm{Zn}^{+}$were determined after digestion of a small cut of the blank gel with $\mathrm{HNO}_{3}$ and measurement using ICP-SFMS. ${ }^{14}$ The optimized experimental parameters of LA-ICP-SFMS and ICPSFMS measurements are summarized in Table 1.

\subsection{Standards and reagents}

Concentrated nitric acid of Supragrade purity from Merck (Darmstadt, Germany) was used for sample digestion. Phosphorus, sulfur, silicon, aluminium, copper and zinc standard stock solutions for the calibration procedures were obtained from Merck (Darmstadt, Germany) and from the National Institute of Standards and Technology (NIST). For all dilutions, deionized Milli-Q water (18 M $\Omega$ ) was used from a Millipore Milli-Q-Plus water purifier.

A certified standard (CRM) BCR-273 (single-cell proteins with a $\mathrm{P}$ concentration of $26.8 \pm 0.4 \mathrm{mg} \mathrm{g}^{-1}$ ) was obtained from IRMM (Geel, Belgium). The results of analysis of BCR273 were mainly reported in a previous paper. We found that BCR-273 is not suited to microlocal analysis by LA-ICP-MS owing to serious inhomogeneity of the CRM. ${ }^{3}$

\subsection{Samples and sample preparation}

Human brain samples obtained post mortem from patients with Alzheimer's disease were analysed for phosphorus, sulfur, copper, aluminium, silicon and zinc content by LA-ICP-MS after 2-D gel electrophoresis directly. For preparation of the

Table 1 Experimental parameters for LA-ICP-SFMS and ICP-SFMS ${ }^{a}$

\begin{tabular}{|c|c|c|}
\hline Technique & LA-ICP-SFMS & ICP-SFMS \\
\hline Laser ablation system & $\begin{array}{l}\text { LSX } 200 \\
\text { (CETAC) }\end{array}$ & \\
\hline Nebulizer type & $\begin{array}{l}\text { USN (for } \\
\text { calibration) }\end{array}$ & Microconcentr \\
\hline Spray chamber & With desolvator & Minicyclonic \\
\hline Rf power/W & 1250 & 1200 \\
\hline Cooling gas flow rate $/ 1 \mathrm{~min}^{-1}$ & 18 & 14 \\
\hline Auxiliary gas flow rate/l $\mathrm{min}^{-1}$ & 1.1 & 1.4 \\
\hline $\begin{array}{l}\text { Nebulizer (carrier) gas flow } \\
\text { rate/l } \mathrm{min}^{-1}\end{array}$ & 1.32 & 0.7 \\
\hline Solution uptake rate $/ \mathrm{ml} \mathrm{min}^{-1}$ & 2 & 0.05 \\
\hline Extraction lens potential/V & 2000 & 2000 \\
\hline Mass resolution $(m / \Delta m)$ & 4000 & 4000 \\
\hline Analysis time/min & 5 & 5 \\
\hline Number of runs & 6 & 20 \\
\hline Number of blocks of runs & 5 & 6 \\
\hline
\end{tabular}

${ }^{a}$ Element (Finnigan MAT) for determination of $\mathrm{P}, \mathrm{S}, \mathrm{Al}, \mathrm{Si}, \mathrm{Cu}$ and $\mathrm{Zn}$ in proteins. brain sample for 2-D electrophoresis cell lysis and afterwards ultracentrifugation were used. For the lysis a buffer system with different proteases (e.g., aprotinin, antipain, leupeptin, pepstatin, from Sigma, Deisenhofen, Germany) was applied.

\subsection{Protein separation by two-dimensional gel electrophoresis}

The 2-D gel electrophoresis separation of serum samples was performed as described by Tissot et al. ${ }^{15}$ Isoelectric focusing (IEF) in the first step was carried out on Immobiline DryStrip gels (immobilized $\mathrm{pH}$ gradient strip) with $\mathrm{pH} 4-7$ and 3-10. All protein separations were performed and the selected separated proteins on the gel were analysed in respect of $\mathrm{P}, \mathrm{S}, \mathrm{Si}, \mathrm{Al}, \mathrm{Cu}$ and $\mathrm{Zn}$ directly by LA-ICP-MS. For future identification of separated protein spots by MALDI-FTICR-MS a duplicate gel was prepared under the same experimental conditions. After two-dimensional electrophoretic separation the gel was dried for several days before LA-ICP-MS measurements were carried out.

\section{Results and discussion}

3.1. Separation and isolation of proteins by two-dimensional gel electrophoresis

Fig. 1 shows a graph of a 2-D gel separation of human proteins (Alzheimer's disease) with different well-separated protein spots. At the standard conditions of isoelectric focusing and separation (see Experimental), the major and medium-abundant proteins are well resolved within the Immobiline $\mathrm{pH}$ gradients 4-7.

In this work selected protein spots (marked by 1-9) are analyzed by LA-ICP-MS. Several areas from these 2-D gels were employed as references and gel blanks for elemental determinations by LA-ICP-MS, as described below.

\subsection{Determination of element ratios in protein spots after separation of 2-D gel electrophoresis by LA-ICP-SFMS}

LA-ICP-MS is a promising surface analytical technique for the direct $\mu$-local analysis of protein spots in a two-dimensional gel, whereby rapidly and simultaneously the existence of $\mathrm{P}, \mathrm{S}, \mathrm{Al}$, $\mathrm{Cu}, \mathrm{Zn}$ and other elements in several proteins can be detected. Owing to high background of elements studied in the gel blank, it was sometimes difficult to analyze these elements in protein

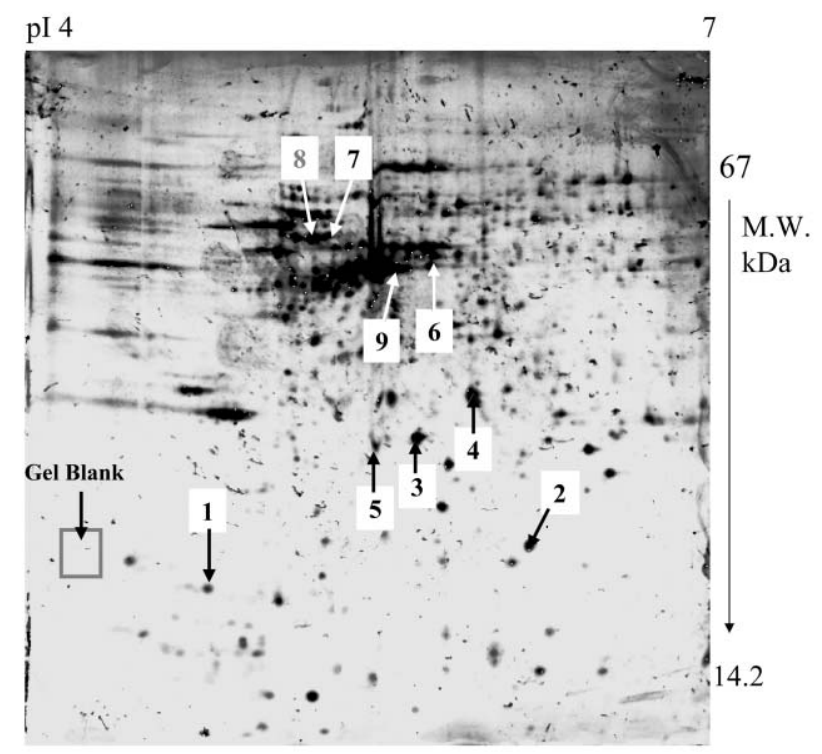

Fig. 1 2-D gel electrophoresis separation of Alzheimer's disease brain proteins within $\mathrm{pH}$ 4-7 using Immobiline gel strip; staining was performed with silver staining. 
Table 2 Qualitative results of element determination on protein spots in gel by LA-ICP-MS

\begin{tabular}{lcccccc}
\hline Spot & $\mathrm{S}$ & $\mathrm{P}$ & $\mathrm{Si}$ & $\mathrm{Cu}$ & $\mathrm{Al}$ & $\mathrm{Zn}$ \\
\hline 1 & - & - & - & - & - & - \\
2 & - & - & - & - & - & - \\
3 & + & - & - & - & - & - \\
4 & - & - & - & - & - & - \\
5 & + & + & - & - & - & - \\
6 & + & + & - & $(+)$ & $(+)$ & + \\
7 & + & + & + & + & + & + \\
8 & + & + & + & + & + & + \\
9 & $(+)$ & + & + & + & $(+)$ & $(+)$ \\
Detection limit ${ }^{a} / \mu \mathrm{g}^{-1}$ & 150 & 0.6 & 2700 & 15 & 0.6 & 397 \\
${ }^{a}$ In gel blank measured by $\mathrm{ICP}-\mathrm{MS}$ after digestion. & &
\end{tabular}

spots. Table 2 summarizes the qualitative results of LA-ICPMS on investigated protein spots in the gels and the detection limits of elements measured in the gel blank.

In protein spots 1, 2 and 4, no element studied was found in comparison with the background intensity in the gel. In protein spot 3, only sulfur (about 3-4 times higher than the background signal) was measured. Whereas for $\mathrm{P}$ and $\mathrm{Cu}$, continuous background signals in the LA-ICP mass spectra for different $\mu$-local analysis in the blank and investigated spots were observed, transient signals were measured for sulfur in the investigated gel spots and blank. The detection limit of phosphorus in protein spots was determined to be $0.6 \mu \mathrm{g} \mathrm{g}^{-1}$.

In protein spot 5 , mainly $\mathrm{P}$ and $\mathrm{S}$ were detected. The relative ion intensities of ${ }^{31} \mathrm{P}^{+}$and ${ }^{32} \mathrm{~S}^{+}$measured by LA-ICP-MS for the protein spot 5 are shown in Fig. 2. The ion intensity of phosphorus in the protein spot was determined to be about a factor of 6-7 higher than the background intensity. For the other elements studied, continuous background signals were observed.

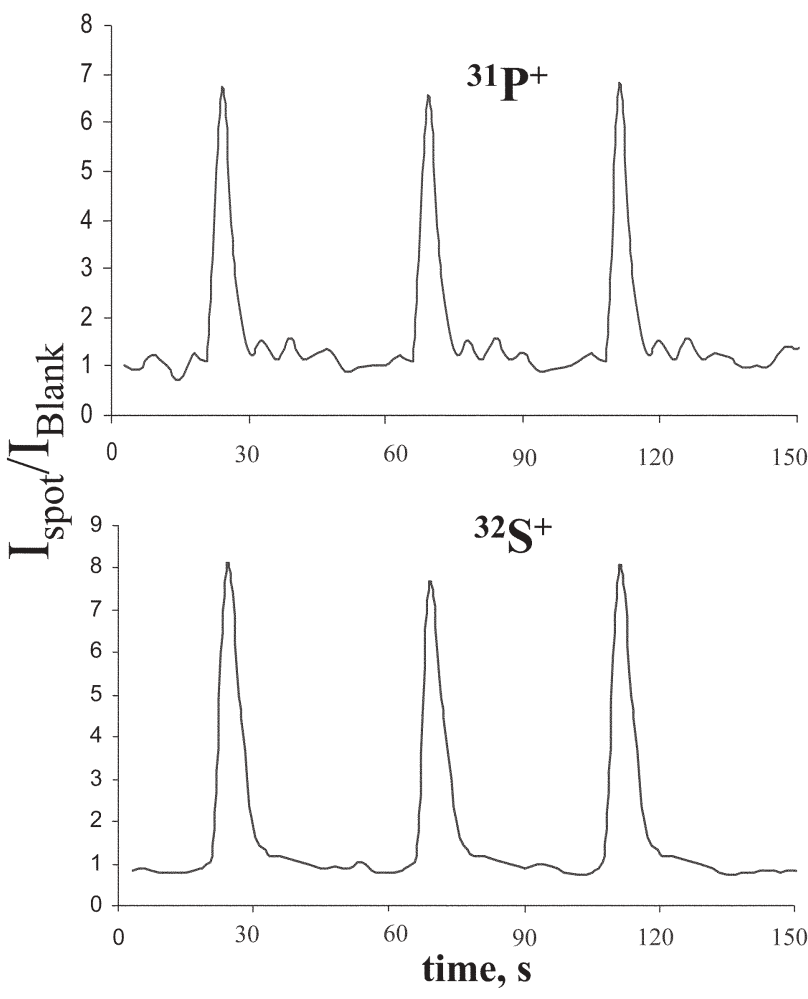

Fig. 2 Transient signals of ${ }^{31} \mathrm{P}^{+}$and ${ }^{32} \mathrm{~S}^{+}$in protein spot 5 .

Of special interest are protein spots 6-9, where a multielement analysis of several analytes via transient signals was possible. Fig. 3 compares the ion intensities of analytes in these proteins in comparison to background signal in gel blank.
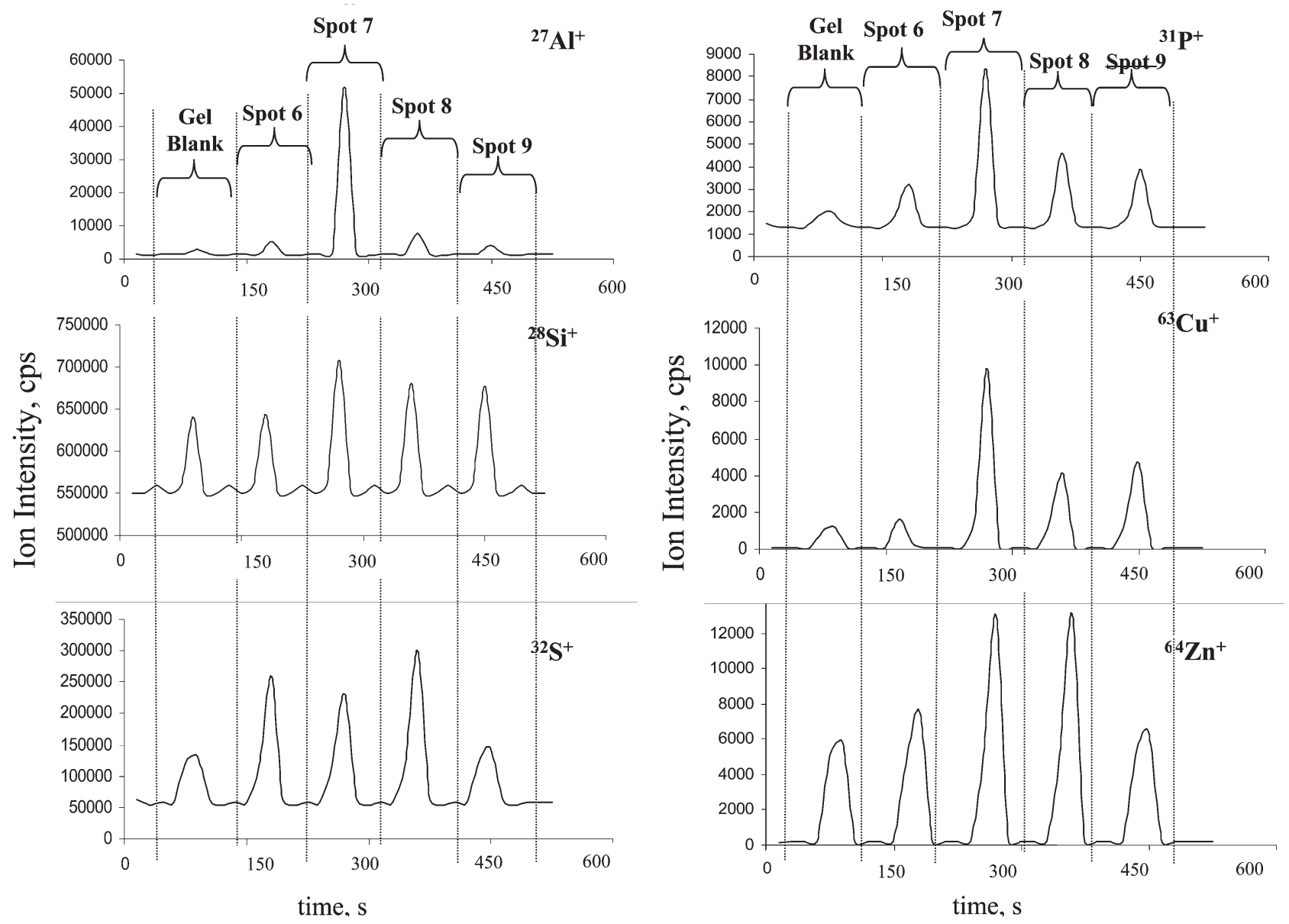

Fig. 3 Transient signals of ${ }^{27} \mathrm{Al}^{+},{ }^{28} \mathrm{Si}^{+},{ }^{31} \mathrm{P}^{+},{ }^{32} \mathrm{~S}^{+},{ }^{63} \mathrm{Cu}^{+}$and ${ }^{64} \mathrm{Zn}^{+}$in protein spots $6-9$ in comparison with the blank gel. 
Table 3 Element ratios in protein spots measured by LA-ICPMS. Relative standard deviation (RSD) of measured element ratios is about $30 \%$

\begin{tabular}{lllll}
\hline Element ratios & Spot 5 & Spot 6 & Spot 7 & Spot 8 \\
\hline $\mathrm{Al} / \mathrm{S}$ & - & 0.003 & 0.49 & 0.033 \\
$\mathrm{Si} / \mathrm{S}$ & - & 0.52 & 0.75 & 0.29 \\
$\mathrm{P} / \mathrm{S}$ & 0.323 & 0.002 & 0.063 & 0.017 \\
$\mathrm{Cu} / \mathrm{S}$ & - & 0.066 & 0.13 & 0.028 \\
$\mathrm{Zn} / \mathrm{S}$ & - & 1.53 & 0.15 & 0.10 \\
\hline
\end{tabular}

Transient ion signals of ${ }^{31} \mathrm{P}^{+},{ }^{63} \mathrm{Cu}^{+},{ }^{27} \mathrm{Al}^{+},{ }^{64} \mathrm{Zn}^{+},{ }^{28} \mathrm{Si}^{+}$and ${ }^{32} \mathrm{~S}^{+}$in different protein spots measured by LA-ICP-SFMS with 500 laser shots using single point $\mu$-local analysis are shown. The highest ion intensity of $\mathrm{Al}^{+}$in the protein of spot 7 correlates with relative high $\mathrm{P}^{+}, \mathrm{Cu}^{+}$and $\mathrm{Zn}^{+}$ion intensities. In contrast, the protein in spot 8 , which also contains all elements studied by LA-ICP-MS, shows similar signal intensity for $\mathrm{Zn}^{+}$but lesser intensities for $\mathrm{Al}^{+}, \mathrm{Cu}^{+}$and $\mathrm{P}^{+}$.

Concentrations of $\mathrm{P}$ and $\mathrm{S}$ in the blank gel were 0.010 and $0.052 \mathrm{mg} \mathrm{g}^{-1}$, respectively, measured by ICP-MS after digestion. These values are, in comparison with former measurements on Coomassie stained gels (background of $\mathrm{P}$ and $\mathrm{S}$ measured by LA-ICP-MS: 0.11 and $0.39 \mathrm{mg} \mathrm{g}^{-1}$, respectively ${ }^{3,14}$ ), an improvement for $\mathrm{P}$ background of about one order of magnitude, whereas the background of sulfur in silver staining gel is better by a factor of 7.5. Phosphorus concentrations in protein spots (assuming one phosphorylation site per protein molecule) were estimated to be detectable at $\geqslant 0.598 \times 10^{-6} \mathrm{~g} \mathrm{~g}^{-1}$ by LA-ICP-MS. Owing to the high background of some elements in the gel (e.g., Si), the detection limit of LA-ICP-MS is relatively high.

An investigation via depth profiling by $\mu$-local LA-ICP-MS on protein spots showed that, in most cases, the maximum $\mathrm{P}$ and $\mathrm{S}$ concentrations were found on one of the surfaces of the gel. Also in these measurements, concentrations of $\mathrm{P}$ and $\mathrm{S}$ changed with changing gel depth, but the ratio of $\mathrm{P} / \mathrm{S}$ remained constant within measurement error. A lateral analysis of element distribution in the protein spots yielded maximum intensities for measured analyte ions in the middle of spot where the highest protein amount is concentrated. In the future, by scanning the laser beam over the gel surface the distribution of the elements will be studied.

Whereas, by LA-ICP-MS, a direct $\mu$-local analysis of separated protein spots is possible, ICP-MS analysis requires a small trypsin (or $\mathrm{HNO}_{3}$ ) digested solution of protein spots from a gel. A major problem in element determination by ICPMS in digested protein spots from gel is the possible contamination of the sample during the sample preparation. ${ }^{14}$ In LA-ICP-MS, the contamination problems can be minimized and therefore this technique provides an accurate analyte concentration if the sulfur content in the protein is known: therefore $\mathrm{S}$ was chosen in recent work ${ }^{3}$ as a suitable internal standard element. On the other hand, element ratios (e.g., $\mathrm{P} / \mathrm{S}$, $\mathrm{Cu} / \mathrm{S}, \mathrm{Zn} / \mathrm{S}$ ) of proteins can be determined. For example, in Table 3 the element ratios in the proteins 5-8 are summarized. The concentration of analyte $\mathrm{X}$ is mostly lower than the sulfur content, the element ratio $\mathrm{X} / \mathrm{S}$ varied in different protein spots down to 0.003 .

When ablating proteins from the wet gel the analyzed material is evaporated rapidly from the gel surface. In the case of single ion detector ICP-MS, the detector must switch from one isotope to another. In addition, the possible instability of the mass calibration at medium mass resolution in the ICPSFMS applied required a relatively wide mass window to be scanned, which resulted in longer scanning time per isotope and was disadvantageous when monitoring fast processes, especially if multielemental analysis was being performed. Therefore, in this case, a multiple ion collector ICP-MS would be beneficial because it allows determination of several analytes, e.g., ${ }^{31} \mathrm{P}^{+},{ }^{27} \mathrm{Al}^{+},{ }^{28} \mathrm{Si}^{+}$and ${ }^{32} \mathrm{~S}^{+}$, simultaneously. Future work will be focused on developing a new screening technique for two-dimensional gels to detect fast phosphorus, sulfur and metals in well-separated protein spots, development of a quantification procedure by LA-ICP-MS and identification of proteins by high resolution MALDI-FTICR-MS.

\section{Conclusions}

In the present study we demonstrated the multielement determination in separated protein spots of two-dimensional gels by LA-ICP-MS as the microlocal analytical techniques. By application of LA-ICP-MS using a sector field mass spectrometer, interfering molecular ions such as ${ }^{15} \mathrm{~N}^{16} \mathrm{O}^{+}$and ${ }^{14} \mathrm{~N}^{16} \mathrm{O}^{1} \mathrm{H}^{+}$can be separated from analyte ions ${ }^{31} \mathrm{P}^{+}$, which is crucial for accurate phosphorus determinations in protein spots. The most important problem for the determination of phosphorus and other elements in the gel are possible contaminations during sample preparation. Future work will focus on further minimizing the gel blank with respect to other elements by improving the 2-D gel electrophoretic separation of proteins and avoiding possible contamination.

\section{Acknowledgements}

The work at the University of Konstanz was supported by the Deutsche Forschungsgemeinschaft, Bonn, Germany (BiopolymerMS). The first author is also very grateful to H.-J. Dietze (Juelich) and A. Vonderheide (Cincinnati) for valuable discussions.

\section{References}

1 J. S. Becker, Spectrochim. Acta, 2002, 57, 1805.

2 S. F. Durrant, J. Anal. At. Spectrom., 1999, 14, 1385

3 J. S. Becker, S. F. Boulyga, J. Su. Becker, C. Pickhardt, E. Damoc and M. Przybylski, Int. J. Mass Spectrom., 2003, 228, 985.

4 J. L. Neilsen, A. Abildtrup, J. Christensen, P. Watson, A. Cox and C. W. McLeod, Spectrochim. Acta, Part B, 1998, 53, 339.

5 P. Marshall, O. Heudi, S. Bains, H. N. Freeman, F. Abou-Shakra and K. Reardon, Analyst, 2002, 127, 459.

6 V. I. Baranov, Z. A. Quinn, D. R. Bandura and S. D. Tanner, J. Anal. At. Spectrom., 2002, 17, 1148.

7 S. F. Boulyga, C. Pickhardt, J. Su. Becker, M. Przybylski and J. S. Becker, in Plasma Source Mass Spectrometry, eds. G. Holland and S. D. Tanner, The Royal Society of Chemistry, Cambridge, 2003, p. 55

8 Protein Phosphorylation, eds. B. M. Sefton and T. Hunter, Academic Press; San Diego, CA, 1st edn., 1998.

9 M. J. Davies, R. T. Dean and D. Davies, Radical-Mediated Protein Oxidation: From Chemistry to Medicine, Oxford University Press, Oxford, UK, 1998.

10 A. V. Loboda, A. N. Kruchinsky, M. Bromirski, W. Ens and K. G. Standing, Rapid Commun. Mass Spectrom., 2000, 14, 1047.

11 K. L. Bennett, A. Stensballe, A. V. Podtelejnikov, M. Moniatte and O. N. Jensen, J. Mass Spectrom., 2002, 37, 179.

12 T. A. Fligge, C. Reinhard, C. Harter, F. T. Wieland and M. Przybylski, Biochemistry, 2000, 39, 8491 .

13 J. S. Rossier, N. Youhnovski, N. Lion, E. Damoc, J. Su. Becker, F. Reymond, H. H. Girault and M. Przybylski, Angew. Chem. Int. Edn. Engl., 2003, 42, 53.

14 J. S. Becker, S. F. Boulyga, C. Pickhardt, J. Su. Becker, S. Buddurus and M. Przybylski, Anal. Bioanal. Chem., 2003, 375, 561 .

15 J.-D. Tissot, F. Invernizzi, J. A. Schifferi, F. Sperteni and P. Schneider, Electrophoresis, 1999, 20, 606.

16 M. Wind, I. Feldmann, N. Jakubowski and W. Lehmann, Electrophoresis, 2003, 24, 1276-1280. 